\begin{tabular}{|c|c|}
\hline Title & $\begin{array}{l}\text { Stepwise fluorometric determination of primary and secondary amines by liquid chromatography } \\
\text { after derivatization with } 2 \text {-methoxy-2, 4-diphenyl-3(2H)-furanone }\end{array}$ \\
\hline \multicolumn{2}{|l|}{ Sub Title } \\
\hline Author & $\begin{array}{l}\text { 中村, 洋(Nakamura, Hiroshi) } \\
\text { 高木, 和子( Takagi, Kazuko) } \\
\text { 田村，善蔵( Tamura, Zenzo) } \\
\text { 与田，玲子( Yoda, Reiko) } \\
\text { 山本，有一( Yamamoto, Yuichi) }\end{array}$ \\
\hline Publisher & 共立薬科大学 \\
\hline Publication year & 1984 \\
\hline Jtitle & $\begin{array}{l}\text { 共立薬科大学研究年報 (The annual report of the Kyoritsu College of } \\
\text { Pharmacy). No.29 (1984. ) ,p.47-48 }\end{array}$ \\
\hline \multicolumn{2}{|l|}{ JaLC DOI } \\
\hline \multicolumn{2}{|l|}{ Abstract } \\
\hline Notes & 抄録 \\
\hline Genre & Technical Report \\
\hline URL & $\begin{array}{l}\text { https://koara.lib.keio.ac.jp/xoonips/modules/xoonips/detail.php?koara_id=AN00062898-0000002 } \\
\text { 9-0047 }\end{array}$ \\
\hline
\end{tabular}

慶應義塾大学学術情報リポジトリ(KOARA)に掲載されているコンテンツの著作権は、それぞれの著作者、学会または出版社/発行者に帰属し、その権利は著作権法によって 保護されています。引用にあたっては、著作権法を遵守してご利用ください。

The copyrights of content available on the KeiO Associated Repository of Academic resources (KOARA) belong to the respective authors, academic societies, or publishers/issuers, and these rights are protected by the Japanese Copyright Act. When quoting the content, please follow the Japanese copyright act. 


\title{
Stepwise Fluorometric Determination of Primary and Secondary Amines by Liquid Chromatography after Derivatization With 2-Methoxy-2,4-diphenyl-3(2 H)-furanone*
}

\author{
Hiroshi Nakamura**, Kazuko Takagi, Zenzo Tamura***, \\ Reiko Yoda and Yuichi Yamamoto \\ 中村 洋**, 高木和子, 田村善蔵***, \\ 与田玲子, (故)山本有一
}

A high-performance liquid chromatographic (HPLC) method was developed for the stepwise fluorometric determination of primary and secondary amines. Amines were reacted with 2-methoxy-2,4-diphenyl-3(2H)-furanone (MDPF) at $\mathrm{pH} 9.6$ and $20^{\circ} \mathrm{C}$ for $30 \mathrm{~min}$ to produce fluorescent pyrrolinones $\left(\mathrm{FI}^{\prime}\right)$ from primary amines and nonfluorescent aminodienones (FII') from secondary amines. The MDPF-adducts of amines were separated on a reversed-phase $\mathrm{C}_{18}$ (TSK LS-410 K) column with a mixture of methanol and $50 \mathrm{mM}$ phosphate buffer $(\mathrm{pH} 7.0)(70: 30)$. After the detection of $\mathrm{FI}^{\prime}$ with the first fluorescence monitor $\left(\lambda_{e x} 360 \mathrm{mn}, \lambda_{e m}>405 \mathrm{~nm}\right.$ ), the eluate was mixed with $12 \mathrm{M}$ ethanolamine hydrochloride ( $\mathrm{pH} 10.5$ ) to convert $\mathrm{FII}^{\prime}$ to fluorescent MDPF-ethanolamine which was detected with the second fluorescence monitor $\left(\lambda_{e x} 390 \mathrm{~nm}, \lambda_{e m} 480 \mathrm{~nm}\right)$.
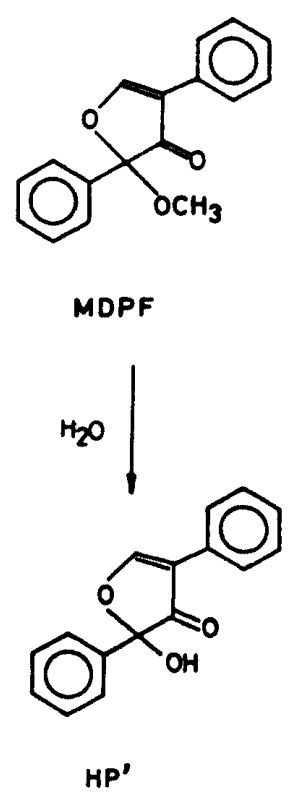
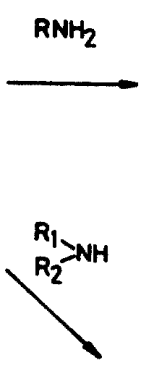<smiles>O=C(Nc1ccccc1)C(=O)c1ccccc1</smiles>

$\mathrm{Fl}^{\prime}$

FII'<smiles>[2H]N1C=C(c2ccccc2)C(=O)C1(O)c1ccccc1</smiles>
$\mathrm{HOCH}_{2} \mathrm{CH}_{2} \mathrm{NH}_{2}$

* 本報告は Anal.Chem., 56, 919 (1984) 飞発表

** 東京大学薬学部

*** 慶応大学医学部 
No. 29 (1984)

The present method permits the determination of 3 pmol of lower $n$-alkylamines and $50 \mathrm{pmol}$ of lower di- $n$-alkylamines. The relative standard deviations were $2.3-2.7 \%$ for 50 pmol of the $n$-alkylamines and $2.9-3.4 \%$ for 1 nmol of the di- $n$-alkylamines. 